\title{
Ribosomal DNA variation among populations of a Pinus rigida Mill. (pitch pine) ecosystem: I. Distribution of copy numbers
}

\author{
DIDDAHALLY R. GOVINDARAJU \& CHRISTOPHER A. CULLIS \\ Department of Biology, Case Western Reserve University, Cleveland, OH 44106, U.S.A.
}

\begin{abstract}
We determined the number and distribution of rRNA genes among individuals of eight pitch pine populations representing a small ecosystem. While these populations show little or no variation for allozymes and also experience high gene flow, they exhibit large amounts of morphological diversity, apparently caused by environmental stress. Nine to ten contigously distributed individuals, located approximately at the centre of the plots in seven out of eight populations, were used toward determining copy numbers. These ranged from 355 to 7356 . Approximately, a 12-fold variation among individuals within populations, and 21-fold variation between the lowest and the highest values, among populations was recorded. Numbers of rDNA copies were found to be lower among populations subjected to environmental stress. We conclude that strong diversifying selection may influence the abundance of rRNA genes among pitch pine populations.
\end{abstract}

Keywords: diversifying selection, molecular drive, multigene families, pitch pine, rDNA copy numbers.

\section{Introduction}

In higher plants, 10-90 per cent of the total genome is composed of repetitive sequences (Flavell, 1983; Murphy \& Thompson, 1988). Although the function and maintenance of a majority of these sequences is obscure, the product of one of them, the ribosomal RNA (rRNA), plays a central role in protein synthesis, and hence is important in growth, development and reproduction (Stern et al., 1989). Ribosomal DNA (rDNA) consists of a tandem array of repeat units varying from 500 to 40,000 copies per genome (Long \& Dawid, 1980; Rogers \& Bendich, 1987). Several workers have attempted to relate variation in the abundance of rRNA genes to phenotypic (quantitative) characters and environmental factors in various organisms. For example, Ritossa et al., (1966) and Frankham et al., (1980) reported that the 'bobbed' phenotype in Drosophila melanogaster, characterized by delayed development and thin short bristles, was associated with low abundance of rDNA. Similarly, Dutton \& Kreider (1985) found a positive relationship between rDNA amount and bristle length, while complete loss of rDNA was lethal. In flax, a higher number of rRNA genes were associated with tall forms, while shorter forms (apparently induced by environ- mental stress) had fewer copies of rRNA genes (Timmis \& Ingle, 1973; Cullis, 1987). In Douglas-fir, Strauss \& Tsai (1988) reported a positive association between a high number of rRNA genes and high altitude Recently, Zhang et al., (1990) did not find a strong association between the rDNA copy numbers and population adaptation to various ecogeographical conditions in barley. However, no data are available on the quantitative variation of rRNA genes among closely located individuals within and among natural populations at the level of an ecosystem, for any forest tree species. In the present study, we report the distribution of rRNA genes among individuals within populations, and among several populations spread across a small pitch pine ecosystem - the Pine Barrens of New Jersey.

Populations of pitch pine in the Pine Barrens of New Jersey have been suggested to have developed dynamically over time and space, imposed by variable fire frequencies (McCormick \& Buell, 1968), leading to the formation of a 'mosaic' landscape (Forman, 1979). This ecosystem is comprised of dry, mesic, aquatic and wetland environments, occupying a contiguous area of approximately 400,000 hectares in the southern portion of New Jersey. Pitch pine shows a large phenotypic amplitude in the Pine Barrens: it grows as a 
shrub (2-4 m) in the East and West Plains, but attains a height of nearly $30 \mathrm{~m}$ in some parts of the ecosystem. The dwarf form in the Pine Plains has been described as an adaptive response to relatively higher fire frequencies (Givnish, 1981 and references therein). In an attempt to study population differentiation between the Plains (dwarf) and the other (tall) populations of the Pine Barrens, Good \& Good (1975) conducted a growth study on progeny obtained from the tall and the dwarf forms and found a statistically significant difference in growth rate between the two forms; they therefore suggested that the contrasting growth patterns may be attributable to genetic differences. On the other hand, Guries \& Ledig (1978), failed to detect a significant variation in gene frequencies between the tall and the dwarf forms using allozyme markers, which may be explained by high levels of gene flow existing among these populations (Govindaraju, 1989a). Moreover, no variation for genome size (haploid DNA content or $C$ value) has been reported among pitch pine populations from its distribution range (Dhillon et al., 1978).

Ribosomal genes belong to a multigene family and are distributed on one or several chromosomes in the genome. In radiata pine (and perhaps in all pines), however, rRNA genes are distributed on several chromosomes (Cullis et al., 1988). The number as well as sequence variation in multigene families may be maintained by a number of processes included in the description of molecular drive (gene conversion, unequal crossing over, replication slippage etc., Dover, 1982), which could lead to homogeneity among individuals and populations. Molecular drive describes intragenomic homogenization (spread of a variant through a gene family) as well as intergenomic fixation in sexual populations. These dual processes could lead to wide fluctuations in copy numbers among individuals (Dover, 1989). The breeding system in highly crosspollinated plants such as pines, offers greater opportunities for the spread as well as fixation of variants among genomes due to high levels of gene flow among individuals and populations (Govindaraju, 1988). Several theoretical and experimental studies on natural populations of both plants and animals have, in fact, shown that numerical and sequence divergence among multigene families may be maintained by selection (Cluster et al., 1987; Stephan, 1989; Templeton et al., 1989; Williams, 1990; Zhang et al., 1990). Therefore, it is likely that pitch pine populations in the Pine Barrens may show varying abundance of copy numbers. The present study has the following objectives: (a) to test the null hypothesis that there is no divergence for rDNA copy numbers, and (b) to examine if there is a qualitative association between copy numbers and environmental variation among closely located pitch pine populations from the Pine Barrens of New Jersey.

\section{Materials and methods}

The study consisted of 77 individuals representing eight sites in the Pine Barrens (Fig. 1; Table 1). Nine to ten individuals measuring at least two inches approximately one foot above the ground level were mapped on to a two-dimensional grid in six out of the eight populations. Individuals from the other two populations were not mapped. Needle tissue was collected from one branch of each of the 77 individuals representing eight localities in the Pine Barrens. Total genomic DNA was extracted from $10 \mathrm{~g}$ of leaf tissue using a CTAB procedure (Wagner et al., 1987), and was suspended in $500 \mu \mathrm{l}-1 \mathrm{ml} \quad 0.1 \times$ Tris-EDTA buffer. This DNA was further diluted to approximately $100-250 \mu \mathrm{g} / \mathrm{ml}$ on the basis of band intensity of uncut genomic DNA on ethidium bromide-stained gels. The diluted DNA was mixed with heat-treated RNAse and proteinase-K to remove RNA and protein respectively [following Maniatis et al., (1989)] and was subsequently extracted with phenol, phenol/chloroform, chloroform, and ethanol precipitated, and the DNA was resuspended in $0.1 \times$ Tris-EDTA to original concentration.

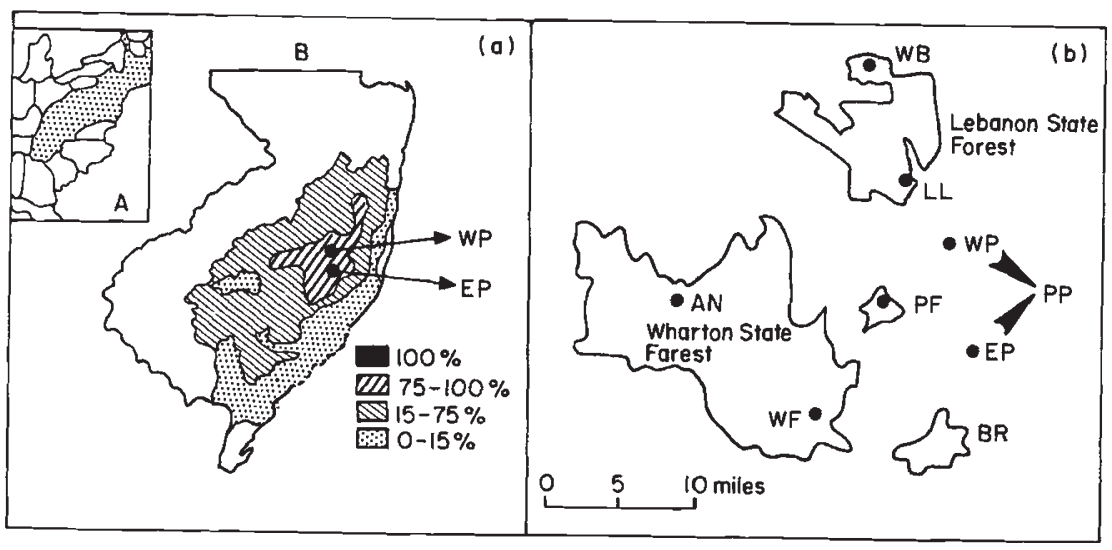

Fig. 1 (a) (A) Entire distribution range of pitch pine, (B) the Pine Barrens of New Jersey; shaded areas (a) represent the degree of cone serotiny in relation to fine frequencies and $(b)$ the locations of pitch pine populations used in the study. 
Table 1 Ecological features of the eight populations from the Pine Barrens

\begin{tabular}{|c|c|c|c|}
\hline Population $\S$ & $n$ & $\begin{array}{l}\text { Density } \\
\text { per acre }\end{array}$ & Description $* \dagger$ \\
\hline White's Bog (WB) & 9 & 375 & $\begin{array}{l}\text { Relatively young stand consisting of saplings and approximately } 25 \text {-year-old trees. } \\
\text { Sandy loam. }\end{array}$ \\
\hline Lebanon Lake $(\mathrm{LL}) \neq$ & 10 & - & Trees between 30 and 60 years of age, $25-50 \mathrm{ft}$ tall. Sandy clay loam. \\
\hline West Plains (WP) & 9 & - & $\begin{array}{l}\text { Dwarf individuals }(4-15 \mathrm{ft}) \text {, and more variation for height, relative to the East Plains } \\
\text { populations. Age structure cannot be determined as a majority of the trees may have } \\
\text { originated from stump sprouts. All individuals have closed (serotinous) cones, which } \\
\text { may be an adaptation to frequent fires. Restricted to sandy site and generally lack } \\
\text { litter cover due to frequent fires. }\end{array}$ \\
\hline East Plains (EP) & 10 & 1486 & $\begin{array}{l}\text { Has all the features of West Plains population except that the individuals are shorter } \\
\text { and show less variation for height. }\end{array}$ \\
\hline Penn Forest $(\mathrm{PF})$ & 9 & 174 & $\begin{array}{l}\text { Mixed age stand, consisting of adult trees ranging in age from } 15 \text { to } 40 \text {. Coarse loamy } \\
\text { soils. }\end{array}$ \\
\hline Bass River (BR) & 10 & 379 & $\begin{array}{l}\text { Mixed age stand, consisting of saplings and nearly } 60 \text {-years-old and } 30-60 \mathrm{ft} \text { trees. } \\
\text { Loamy soil with fluctuating water table. }\end{array}$ \\
\hline Wayne Forest (WF) & 10 & 151 & Relatively young stand, consisting of saplings and $15-25$ year-old trees. Sandy loads. \\
\hline Atsion (AN) & 10 & 2211 & Even-age stand consisting of approximately 25 year-old trees. Sandy site. \\
\hline
\end{tabular}

*Age was determined on the basis of growth features such as needle scars and leader extension and hence approximate.

†Identification of soil types based on detailed soil maps (Anonymous, 1973; Markley, 1979).

¥Individuals distributed over approximately one acre area.

§Contiguously distributed individuals.

The concentration of DNA in each of the samples was estimated by fluorometry (Labarca \& Paigen, 1980; Riley et al., 1989), with a multi-fluorometer (Hoefer Scientific, CA) following the manufacturer's instructions.

The number of rDNA copies was determined by slight modifications of the method outlined by Rivin et al., (1986). Briefly, Zetaprobe (Biorad) membrane of known size was wetted with distilled water and was pasted on to the lower side of the top slab of the slot-blotter (Minifold II; Scleicher \& Schuell). Two layers of Whatman 3MM paper, soaked in $0.4 \mathrm{M}$ $\mathrm{NaOH}$, were placed beneath the membrane and the slot-blot apparatus was assembled. The apparatus was connected to a vacuum, and the wells were filled with $0.4 \mathrm{M} \mathrm{NaOH}$ and the liquid was slowly filtered through. Subsequently, $250 \mathrm{ng}$ of pine DNA, denatured with 4 $\mu \mathrm{l}$ of $4 \mathrm{~m} \mathrm{NaOH}, 0.1 \times \mathrm{TE}$ (total volume $=100 \mu \mathrm{l}$ ) was placed in microfuge tubes, boiled for $5 \mathrm{~min}$ and cooled on ice. The mixture was briefly vortexed and loaded on to the membrane. Only the centre wells (45 out of 96) were used. Six were loaded at a time, and a gentle vacuum was applied to filter the mixture through the membrane. Similarly, four concentrations of flax rDNA plasmid, pBG-35 (250, 500, 750 and $1000 \mathrm{pg})$ were applied along with $100 \mathrm{ng}$ of herring sperm DNA, as internal standards on each blot. Samples from each population were applied on to a blot in a randomized block design with three replications. The slots were subsequently washed with $250 \mu \mathrm{l}$ of $0.4 \mathrm{M} \mathrm{NaOH}$, and the liquid was removed by vacuum. The blots were later rinsed in $5 \times \mathrm{SSC}$, air-dried and baked under vacuum for $1 \mathrm{~h}$. Each blot was hybridized with labelled pBG-35 using the oligonucleotide procedure (Feinberg \& Vogelstein, 1983). Following hybridization, the blots were washed twice with $0.1 \times$ SSC/0.1 per cent SDS at $55^{\circ} \mathrm{C}$, air-dried for about $5 \mathrm{~min}$, wrapped in plastic sheets and autoradiographed at $-70^{\circ} \mathrm{C}$ for varying lengths of time using pre-flashed Fuji NIF-RX X-ray film with two intensifying screens.

The extent of hybridization of each sample was measured using a densitometer (Shimadzu scanner, model, CS-930). The absolute copy number in each slot was determined as a ratio of hybridizing fragments in pBG-35 and the pine DNA, as outlined by Riven $e t$ al., (1986). The linear response of both plasmid and genomic DNA was also tested independently. An average value was obtained for standards in each blot, which was subsequently used to compare the signal of pine DNA in each of the slots on a given blot. The copy number per individual was later determined as an average value across three replications. Both untransformed as well as log-transformed values of the average number of copies per individual were subjected to oneway ANOVA to test for variation among populations. Similarities among population means were evaluated using Tukey's multiple mean comparison test (Zar, 1984). 


\section{Results and discussion}

Copy number variation, both within and among the eight populations of pitch pine, was noted on the basis of band intensities of the pBG-35 standards and the genomic DNA on the autoradiogram. Linear responses

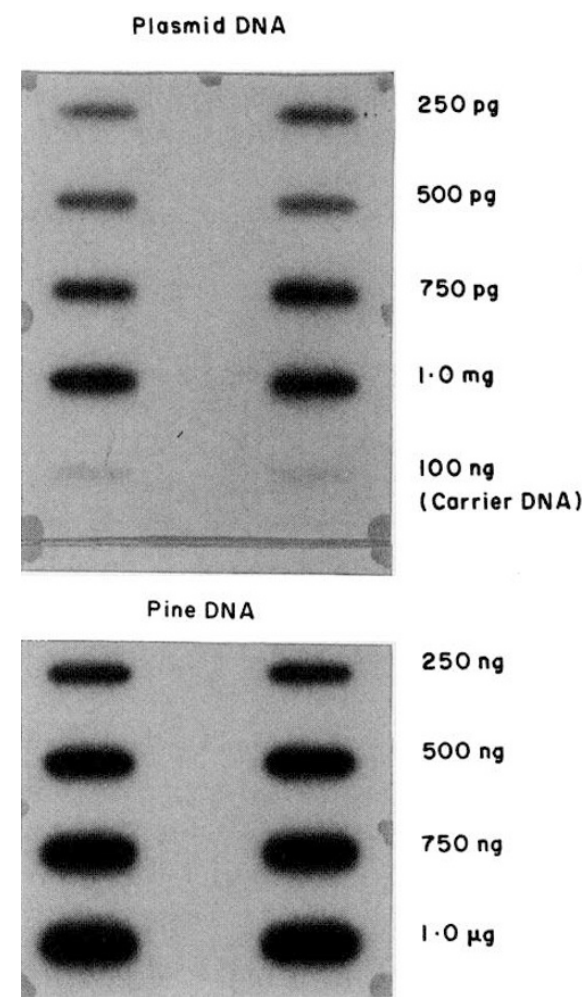

Fig. 2 Linear responses of flax rDNA plasmid pBG35, and pitch pine genomic DNA. Note that the samples were exposed on two separate films for different lengths of time and therefore, the intensity of darkness of the plasmid and the pine DNA bands are mutually exclusive. of both plasmid and the genomic DNA are presented in Fig. 2. The variation of copy numbers among individuals within populations ranged from just twofold in LL and BR populations, to 12 -fold in the WP population. Note, however, that only one out of the nine trees in WP population had 4728 copies, but the other eight trees ranged from 398 to 3132 (data not presented). In addition, there was a 21 -fold difference between the lowest and the highest values among the 77 individuals examined (Table 2). However, rDNA copy numbers in 95 per cent ( 74 out of 77 ) of the individuals included in the study ranged from 737 to 6816 (Fig. 3). A fourfold variation for mean copy numbers was observed among populations which ranged from 1434 in EP to a high of 5416 in LL population. The highest variance was found in PF population, followed by WP, and the lowest was recorded in EP (Table 2). In general, there were two patterns in the dataset: the first group (WB, LL, PF and BR) showed high (mean $=4923)$ numbers; while the second group (WP, EP, WF and AN) recorded lower (mean $=1597$ ) numbers, and these differences were significant $(t$-test; $P<0.001)$. Tukey's multiple sample comparison test also identified two groups, and no significant difference among populations within each of the two groups was noticed (Table $2)$. The variation among populations was significant $(P<0.01)$.

Ribosomal DNA copy number variations have been reported both within and among individuals and populations of various plant species. For example, Rogers \& Bendich (1987) reported a 12-fold variation within individuals, but almost a 95-fold difference among individuals within a population of Vicia faba. In maize, Buescher et al., (1984), reported a 4.6-fold difference among individuals; while Zhang et al., (1990) found a 6.4-fold difference among individuals

Table 2 Copy number variation among the eight pitch pine populations: descriptive statistics and mean comparisons

\begin{tabular}{lcccc}
\hline Population & Mean & s.d. & Minimum & Maximum \\
\hline White's Bog & 4438 & 1368 & 1685 & 5899 \\
Lebanon Lake & 5416 & 1231 & 3482 & 7288 \\
West Plains & 1754 & 1427 & 398 & 4728 \\
East Plains & 1434 & 528 & 355 & 2255 \\
Penn Forest & 5239 & 1528 & 3509 & 7356 \\
Bass River & 4598 & 1399 & 2602 & 6816 \\
Wayne Forest & 1743 & 703 & 737 & 2666 \\
Atsion & 1459 & 1054 & 816 & 4346 \\
Average & 3260 & - & - & - \\
Rank of mean copy number per population & EP AN WF WP & WB BR PF LL* \\
\hline
\end{tabular}

*Similarity of means within each group is denoted by a line. 


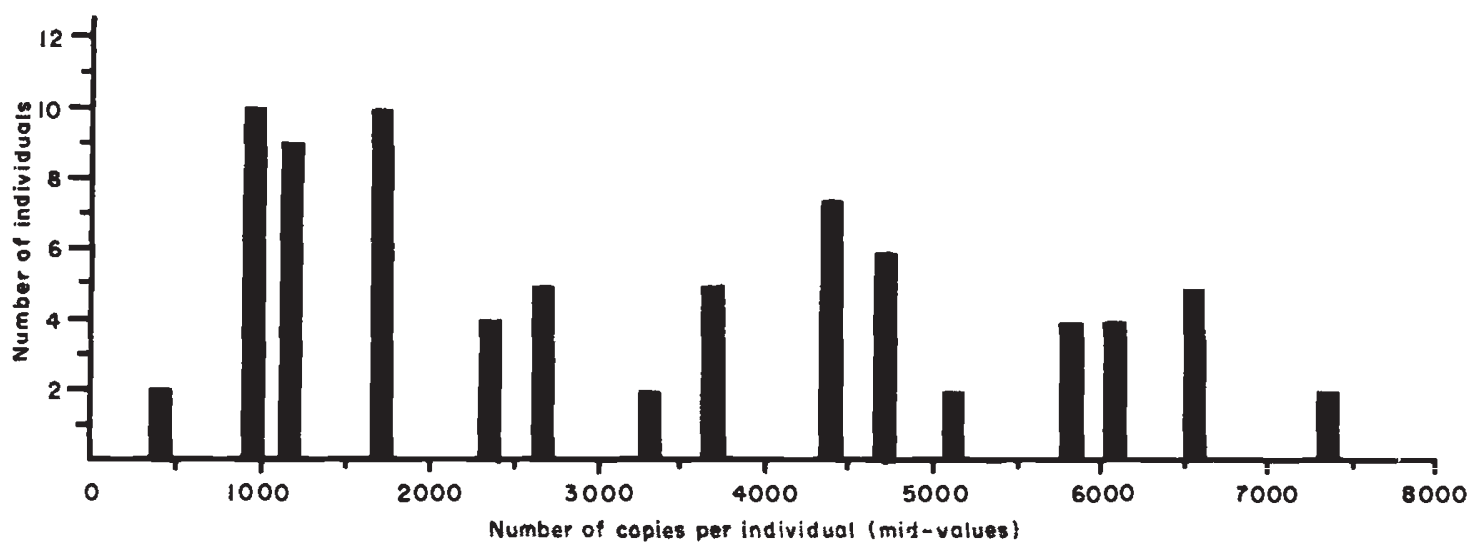

Fig. 3 Distribution of copy numbers (mid-values) among individuals $(n=77)$.

of barley. Among forest tree species, Strauss \& Tsai (1988), reported a fivefold variation in Douglas-fir. In radiata pine, a 20 -fold and a fivefold variation among individuals and populations, respectively, has been recorded (C. A. Cullis \& R. T. Teasdale, unpublished data). The results of the present study generally agree with previous work on rDNA copy number variation in different plant species.

Individuals of the East Plains population showed the lowest number (1434) of rRNA genes followed by the Atsion and the West Plains populations; while the Lebanon Lake populations revealed the highest number (5416). The East and the West Plains populations represent the 'dwarf' individuals found in the Pine Barrens ecosystem. The dwarf nature of these populations has been described as an apparent adaptation to higher fire frequencies relative to the other parts of the Pine Barrens, as well as to the distribution range of pitch pine (Ledig \& Fryer, 1973; Good \& Good, 1975; Givnish, 1981). Thus, while it is reasonable to assume that fire-related stress may have affected both the rDNA copy numbers as well as morphology of individuals of EP and WP populations, AN and WF do not share morphological similarities with the individuals from the Plains' (WP and EP) populations. Geographically, PF and BR populations are wedged between WP, EP and AN and WF (Fig. 1), and yet show high copy numbers. Compared to WB, LL, PF and $\mathrm{BR}$ the individuals of $\mathrm{AN}$ and WF populations generally showed poor growth (Table 1 and D. R. G. personal observations). Nonetheless, the poor growth was not comparable to dwarf individuals found in EP and WP populations. These results, therefore, are consistent with the suggestion that environmental stress may contribute toward reducing the abundance of rDNA copy numbers. However, the reduced copy numbers may not have the single most important effect on morphological variability.
Many attempts have been made to establish the relationship between the abundance of rDNA copies and morphological variation. For example, using several inbred lines of corn Buescher et al., (1984) reported no relationship between rDNA copy numbers and growth performance. Recently, Zhang et al., (1990) observed low copy numbers among individuals collected from localities that received high or low rainfall. These results led them to conclude that '... the erratic variations observed suggest that copy number is at the most, weakly associated with adaptedness'. The results of our study, although similar to those of Zhang et al., differ in detail: three out of four populations (WP, EP and AN) that showed low copy numbers grow on sandy soils, and the WF population is interspersed with hardwood vegetation, but pitch pine individuals of WF and $\mathrm{AN}$ share a great deal of morphological similarities as well as growing conditions (Anonymous, 1973; Markley, 1979). In contrast, individuals representing WB, LL, PF and BR populations are well-developed (Table 1) and are also interspersed with diverse vegetation, indicating relatively better growing conditions. Therefore, while these results indicate a relatively stronger association between low copy numbers and environmental stress rather than copy numbers and morphology, only detailed analysis of all three parameters, namely, environmental stress, morphology and rDNA copy numbers (e.g. Govindaraju \& Dancik, 1987a, b; Nevo, 1988) could provide a more accurate description of the dynamics of these associations.

Ribosomal RNA genes belong to a multigene family, which arose by gene duplication and recombination (MacIntyre, 1976; Ohta, 1990). These types of gene family are subjected to molecular drive, which includes forces such as mutation, unequal crossingover, unequal sister chromatid exchange, replication slippage, gene conversion and random genetic drift (Ohta \& Dover, 1983; Ohta, 1988). Many of these 
forces, specifically unequal exchange events, could lead to deletion or duplication of individual copies as well as homogenization of variants within genomes ( $\mathrm{Li} \&$ Graur, 1991). Organisms such as pines experience conflicting forces which affect the abundance of repetitive sequences. On the one hand, they experience very high levels of gene flow, which could provide greater opportunity for the spread of repeat variants among genomes (individuals), on the other hand, they are also characterized by long and overlapping generation cycles which might retard the rate of spread of repeat units among individuals and populations. The length of generation time is known to affect the rate of accumulation and deletion of DNA sequences (Kohne, 1970). According to Dover (1989), the extent to which natural selection influences new variants depends on 'the ecology and ontogeny of individuals'. Thus, it is likely that rDNA copy numbers among pitch pine populations in the Pine Barrens may be modulated by the combined effects of the internal dynamics of the genome (molecular drive) and the external evolutionary agents such as selection.

The rDNA copy number variation in this study was based on one sample per individual and 9-10 individuals per population. Therefore, no conclusion can be drawn about, (a) intra-individual variation for copy numbers, (b) absolute maximum and minimum number of copies among individuals in any given population, and (c) if there are clines (smooth vs. stepped; Endler, 1977) for copy numbers between populations in relation to environmental gradients. Variation for rRNA genes within individuals has been reported in organisms such as Drosophila (Tartoff, 1975), Neurospora (Russell \& Rodland, 1986) and Vicia (Rogers \& Bendich, 1987). Pitch pine is known to sprout by means of epicormic buds (buds under bark) following fire. Therefore, somatic variation within a tree may have gone undetected. We believe, however, that intraindividual variation may be minimum if any because, in sitka spruce, Strauss \& Howe (1990) failed to detect any measurable difference for rDNA copy numbers among branches separated by hundreds of years. Increased sample sizes per population, sampling individuals along transects to include environmental gradients, accurate description of environmental stresses and age structure are necessary in future studies.

The Pine Barrens ecosystem is a 'mosaic' landscape consisting of highly heterogeneous environments (Forman, 1979), which could allow varied levels of selection intensities (particularly viability selection; Govindaraju, 1989b) to operate among the populations. Furthermore, in species such as pitch pine, which is characterized by many rDNA loci, spread across several chromosomes, reassortment of these loci may lead to individuals with a different number of rRNA genes (Flavell et al., 1986). Individuals carrying a varied number of rRNA genes are further subjected to external evolutionary forces such as selection. Consequently, the 'molecularly driven' copy number distributions may achieve a functional relationship with changing populations (in response to external forces) in their natural environment by a continuous readjustment of genomic families (Dover, 1986, 1989). The two major patterns of rDNA copy number distribution observed in this study may indeed mimic this scenario. Accordingly, the divergent patterns of distribution of rDNA copy numbers among pitch pine populations in the Pine Barrens could be best explained in terms of diversifying selection (Dobzhansky, 1970), due to genotype-environment interactions (Haldane, 1948; Tajima \& Mukai, 1990; Endler, 1986; Wade \& Kalisz, 1990). Such a synergistic interaction of the rDNA multigene family (as well as other multigene families) in response to divergent selective forces may contribute partially to adaptation and evolution of natural populations in heterogeneous environments.

\section{Acknowledgements}

We would like to thank R. Good, R. Montgomerie, R. Schneeberger and F. Zampella for help in various ways, and an anonymous reviewer for invaluable suggestions. DRG is grateful to Drs S. Rogers, M. Timko, R. Vilgalys and S. Williams for discussions. Financial support was provided by the Ohio Board of Regents (CAC) and the American Philosophical Society (DRG).

\section{References}

ANONYMOUS. 1973. Pinelands National Reserve: Soils, nos. 8, 17, 24, 25, 26. NJ Agricultural and Experimental Station, New Brunsuick, NJ.

BUESCHER, P. J., PHILLIPS, R. L. AND BRAMBL, R. 1984. Ribosomal RNA contents of maize genotypes with different ribosomal RNA gene number. Biochem. Genet., 22, 923-930.

CULLIS, C. A. 1987. The generation of somatic and heritable variation in response to stress. Am. Nat., 130, S62-73.

CULLIS, C. A., CRIESSEN, G. P., GORMAN, S. W. AND TEASDALE, R. T. 1988. The 25S, 18 S and 5S ribosomal RNA genes from Pinus radiata D. Don. In: Cheliak, W. M. \& Yapa, Y. C. (eds) Molecular Genetics of Trees. Petawawa National Forestry Institute, Chalk River, Ontario, pp. 34-40.

CluSTER, P. D., MARINCOVIC, D., ALlARD, R. W. AND AYALA, F. J. 1987. Correlation between developmental rates, enzyme activities, ribosomal DNA spacer-length phenotypes, and adaptation in Drosophila melanogaster. Proc. Natl. Acad. Sci. U.S.A., 84, 610-614.

DHILlON, S. S., BERLYN, G. P. AND MIKSCHE, J. P. 1978. Nuclear DNA content in populations of Pinus rigida. Am. J. Bot., 
65, 192-196.

DOBZHANSKy, Th. 1970. Genetics of the Evolutionary Process. Columbia University Press, New York, NY.

DOVER, G. A. 1982. Molecular drive: a cohesive mode of species evolution. Nature, 299, 111-117.

DOVER, G. A. 1986. Molecular drive in multigene families: how biological novelties arise, spread and are assimilated. Trends Genet., 2, 159-165.

DOVER, G. A. 1989. Linkage disequilibrium and molecular drive in the rDNA gene family. Genetics, 122, 249-252.

DUTTON, F. L. AND KRIEDER, H. M. 1985. Expression and amplification of the genes for ribosomal RNA in bobbed mutants of Drosophila melanogaster. Genet. Res., 45, 155-165.

ENDLER, J. A. 1977. Geographic Variation, Speciation and Clines. Princeton University Press, Princeton, NJ.

ENDler, J. A. 1986. Natural Selection in the Wild. Princeton University Press, Princeton, NJ.

FEINBERG, A. P. AND VOGELSTEIN, B. 1983. A technique for radio-labelling DNA restriction endonuclease fragments to high specific activity. Anal. Biochem., 132, 6-13.

FLAVELL, R. B. 1983. Repeated sequences and genome architecture. In: Cifferi, O. \& Dure, L. (eds) Structure and Function of Plant Genomes. Plenum Press, New York, NY, pp. $1-14$.

FLAVELL, R. B., O'DELL, M., SHARP. P., NEVO, E. AND BEILES, A. 1986. Variation in the intergenic spacer of ribosomal DNA of wild wheat, Triticum dicoccoides in Israel. Mol. Biol. Evol., 3, 547-558.

Forman, R. T. T. 1979. The Pine Barrens of New Jersey: An ecological mosaic. In: Forman R. T. T. (ed.) Pine Barrens Ecosystem and Landscape. Academic Press, New York, NY, pp. 569-585.

FRANKHAM, R., BRISCO, D. A. AND NUTHEN, R. K. 1980. Unequal crossing over at the rDNA tandem as a source of quantitative genetic variation. Genetics, 95, 727-745.

GIVNish, T. 1981. Serotiny, geography and fire in the Pine Barrens of New Jersey. Evolution, 35, 101-123.

GOOD, R. AND GOOD, N. 1975. Growth characteristics of populations of Pinus rigida Mill. from the Pine Barrens of New Jersey. Ecology, 56, 1215-1220.

GOVINDARAJu, D. R. 1988. Dispersal ability and levels of gene flow in plants. Oikos, 52, 31-35.

GOVINDARAJU, D. R. 1989a. Estimates of gene flow in forest trees. Biol. J. Linn. Soc., 37, 345-357.

GOVINDARAJU, D. R. 1989b. Viability selection and self-thinning in conifers. Evol. Trends Plants., 3, 121-126.

GOVINDARAJU, D. R. AND DANCIK, B. P. 1987a. Allozyme heterozygosity and homeostasis in germinating seeds of jack pine. Heredity, 59, 279-284.

GOVINDARAJU, D. R. AND DANCIK, B. P. 1987 b. Environmental stresses and the relationship among allozyme heterozygosity, biomass and biomass components in jack pine (Pinus banksiana Lamb.). Genetica, 73, 173-179.

GURIES, R. P. AND LEDIG, F. T. 1978. Analysis of population structure in from allozyme frequencies. Proc. Fourteenth So. For. Tree Improv. Conf., University of Florida, Gainsville, FL. pp. 246-253.

HALDANE, J. B. S. 1948. The interaction of nature and nurture. Ann. Eugen. 13, 197-205.
KOHNE, D. E. 1970. Evolution of higher organism DNA. Quart. Rev. Biophys. 33, 327-375.

LABARCA, C. AND PAIGEN, K. 1980. A simple, rapid and sensitive DNA assay procedure. Anal. Biochem., 102, 344-352.

LEDIG, F. T. AND FRYER, J. H. 1972. A pocket of variability in Pinus rigida. Evolution, 26, 259-266.

LI, W.-H. AND GRAUR, D. 1991. Fundamentals of Molecular Evolution, Sinauer Associates, Inc., Sunderland, MA.

LONG, O. AND DAWID, I. B. 1980. Repeated genes in eukaryotes. Ann. Rev. Biochem., 49, 727-764.

McCORMICK, C. F. AND BUell, M. F. 1968. The Plains: Pigmy forest of New Jersey Pine Barrens, a review and annotated bibliography. Bull. NJ Acad. Sci., 13, 20-34.

MaciNTYRE, R. J. 1976. Evolution and ecological value of duplicate genes. Ann. Rev. Ecol. Syst., 7, 421-468.

MANIATIS, T., FRITSCH, E. F. AND SAMBROOK, J. 1989. Molecular Cloning: A Laboratory Manual. Cold Spring Harbor Laboratory. Cold Spring Harbor, NY.

MARKLEY, M. L. 1979. Soil series of the Pine Barrens. In: Forman R. T. T. (ed.) Pine Barrens Ecosystem And Landscape. Academic Press, New York, NY, pp. 81-93.

MURPHY, T, M. AND THOMPSON, w. F. 1988. Molecular Plant Development. Prentice Hall, Englewood Cliffs, NJ.

NEvo, E. 1988. Genetic diversity in nature: Patterns and theory. Evol. Biol. 23, 217-245.

OHTA, T. 1988. Multigene and supergene families. Oxf. Surv. Evol. Biol., 5, 41-65.

ohta, т. 1990. How gene families evolve. Theor. Pop. Biol., 37, 213-219.

OHTA, T. AND DOVER, G. A. 1983. Population genetics of multigene families that are dispersed in two or more chromosomes. Proc. Natl. Acad. Sci., U.S.A ., 80, 4079-4083.

RILEY, J., JENNER, D., SMITH, J. C. AND MARKHAM, A. F. 1989. Rapid determination of DNA in multiple samples. Nuc. Acids Res., 17, 8383.

Ritossa, F. M., ATwood, K. C. AND SPIEgELman, s. 1966. A molecular explanation of the bobbed mutants of Drosophila as partial deficiencies of 'ribosomal' DNA. Genetics, 54, 819-834.

RIVIN, C., CULLIS, C. A. AND WALBOT, v. 1986. Evaluating quantitative variation in the genome of Zea mays. Genetics, 113, 1009-1019.

ROGERS, S. AND BENDICH, A. J. 1987. Variation in the ribosomal RNA genes among individuals of Vicia faba. Plant Molec. Biol., 9, 509-520.

RUSSELL, P. J. AND RODLAND, K. D. 1986. Magnification of rDNA gene number in a Neurospora crassa strain with a partial deletion of the nucleolus organizer. Chromosoma, 93, 337-340.

STEPHAN, w. 1989. Tandem repetitive non-coding DNA: forms and forces. Molec. Biol. Evol., 6, 198-212.

STERN, S., POERS, T., CHANG-CHIEN, L.-M. AND NOLLER, H. F. 1989. RNA-protein interactions in $30 \mathrm{~S}$ ribosomal subunit; folding and function of 16S rRNA. Science, 244, 783-789.

STRAUSS, S. H. AND HOWE, G. T. 1990. An investigation of somatic variability for ribosomal RNA genes number in old-growth Sitka spruce. Can. J. For. Res., 20, 853-856.

STRAUSS, S. H. AND TSAI, C.-H. 1988. Ribosomal gene number variability in Douglas-fir. J. Hered., 79, 453-458. 
TAJIMA, F. AND MUKAI, T. 1990. Some consideration on diversifying selection. Jap. J. Genet., 65, 193-200.

TARTOFF, K. D. 1975. Redundant genes. Ann. Rev. Genet. 9, 355-385.

TEMPLETON, A. R., HOLLOCHER, H., LAWLER, S. AND JOHNSTON, J. S. 1989. Natural selection and ribosomal DNA in Drosophila. Genome, 31, 296-303.

TIMMIS, J. N. AND INGLE, J. 1973. Environmentally induced changes in rDNA gene redundancy. Nature, 244, 235-236.

WADE, M. J. AND KALISZ, S. 1990. The causes of natural selection. Evolution, 44, 1947-1955.

WAGNER, D. B., FURNIER, G. R., SAGHAI-MAROOF, M. A., WILLIAMS, S.
M., DANCIK, B. P. AND ALlaRD, R. W. 1987. Chloroplast DNA polymorphisms in lodgepole and jack pines and their hybrids. Proc. Natl. Acad. Sci. U.S.A., 84, 2097-2100.

WILLIAMS, S. M. 1990. The opportunity for natural selection in multigene families. Genetics, 124, 439-441.

ZaR, J. H. 1984. Biostatistical Analysis. Prentice-Hall, Inc., Englewood-Cliffs, NJ.

ZHANG, Q., SAGHAI-MAROOF, M. A. AND ALLARD, R. W. 1990. Effects of adaptedness on variations in ribosomal DNA copy number in populations of wild barley (Hordeum vulgare ssp. spontaneum). Proc. Natl. Acad. Sci., U.S.A., 87, 8741-8745. 